\title{
Embryonic and Adult Stem Cells
}

\author{
By Ole Johan Borge
}

The Norwegian Biotechnology Advisory Board, P.B. 522 Sentrum, NO-0105 Oslo, Norway. Tel: + 47222487 91, Fax: + 47222427 45, E-mail: ole.borge@bion.no

Results published in the late 50's and early 60's marked the beginning of the stem cell era. Seminal contributions was made by Ford et al. in 1956 and Till and McCulloch in 1961, demonstrating that lethally irradiated mice could be rescued with cells from freshly isolated bone marrow (10) and that BM cells formed spleen clonies (CFU-S) following transplantation to irradiated recipients (30), respectively.

There is no uniform definition of stem cells, but they are characterized by being i) undifferentiated, ii) having the potential to produce specialized differentiated cells for a long period of time, and iii) postulated to be capable of maintaining or expanding the number of stem cells (i.e. self-renew).

There are different types of stem cells that best can be described in the context of normal human development (23). A fertilized egg is totipotent, meaning that its potential is total, and as the fertilized egg divides all the cells in the embryo remain totipotent until the fertilized egg has reached the 8/16-cell stage. In theory, and to some extent in practice, an 8-cell embryo can be divided into eight single cells, and each cell has the potential of generating an individual if implanted in a woman's uterus. This technique is called cloning by "embryo-splitting" and has been performed in several species including monkeys (5).

Approximately five days after fertilization the totipotent cells have differentiated and started to form a hollow sphere of cells called a blastocyst. The blastocyst has an outer layer of cells, and inside there is a cluster of cells called the "inner cell mass". A few of the cells in the inner cell mass will develop into the foetus, whereas the rest will form the placenta and other supporting tissues needed for foetal development in the uterus. The cells giving rise to the foetus, are called pluripotent embryonic stem cells, since they can form every cell type in the body. However, they cannot form an organism because they are unable to give rise to extra embryonic tissue essential for normal development in the uterus. Embryonic stem (ES) cell lines were isolated from mice in $1981(9,20)$, monkeys in 1995 (29), and humans in 1998 (28).

Pluripotent stem cells are also found in certain regions of the developing fetus and have been derived from 5-9 weeks old aborted human fetuses (26). These cells are commonly termed embryonic germ (EG) cells because they are derived from primordial germ cells found at the genital ridges in developing fetuses.

The pluripotent stem cells differentiate further into cells commonly called multipotent stem cells. These stem cells are considered committed to certain cell lineages. Examples of multipotent stem cells are those producing blood, nerve and muscle cells. Multipotent stem cells are present in the adult individual as well as the fetus and umbilical cord.

\section{Stem cells from adults}

It has been suggested that adults contain 20 different types of stem cells. Hematopoietic 
(blood forming) stem cells have been investigated for several decades and is currently by far the best characterized stem cell system. Until recently it was considered a fact that, for example, hematopoietic stem cells did not have the potential to differentiate into cells of other types than the cells constituting the blood system. The same applied to stem cells in other tissues, such as the brain, muscle, endothelium, liver etc. The established dogma has however been challenged by recent findings suggesting that multipotent stem cells have a broader differentiation potential than previously thought. For example it has been indicated that nerve cells have changed their fate and started to produce functional blood cells (2) and vice versa (22). Likewise, stem cells in skeletal muscle have been proposed to generate blood (13) and vice versa (18). Even more surprisingly, nerve stem cells generated nearly all cell types in developing fetuses when transferred into the cavity of blastocysts (8).

A recent study indicates that even adult humans might harbor cells resembling pluripotent embryonic stem cells. Verfaillie and coworkers (14) demonstrated that cells isolated from the bone marrow could be cultured for prolonged periods of time and differentiate both in vitro and in vivo into a vide variety of seemingly normal cells.

Although several reports indicate an ability of multipotent stem cells to produce cells even outside their normal limits, most of these findings remain highly controversial. This is mainly due to i) lack of reproducibility $(4,16,21)$, ii) the effects have not been demonstrated at the single cell level and iii) it has been demonstrated that the reported findings might be artifacts of the methods used $(27,32)$.

\section{Embryonic stem cells}

In order to establish embryonic stem cell lines, the inner cell mass of blastocyst stage embryos is cultured in the presence of serum and mitotically inactivated murine feeder layers (28). Human embryonic stem cells have a populationdoubling time of about 36 hours and can be propagated for prolonged periods in serum free media supplemented with basic fibroblast growth factor (bFGF).

Human embryonic stem cells can, when induced to differentiate, develop into a variety of cell types. This property makes them valuable as a model system to study the mechanisms regulating lineage commitment and differentiation. In particular, the system enables detailed studies of early development with regard to extrinsic and intrinsic regulators as well as enabling gene knock-out/in studies not commonly available in human model systems.

\section{Stem cells in the clinic}

Stem cells are currently only being used to a limited extent in routine clinical practice. Bone marrow transplantation of cancer patients is the most known example. However, there is considerable hope that stem cells can be utilized in the treatment of a wide array of human disorders by replenishing lost or unfunctional cells. Diseases like Alzheimers, Parkinson, immune deficiencies, anemia and type I diabetes are all candidate diseases potentially suitable for stem cellaided therapy. A number of clinical trails with adult as well as foetal stem cells are ongoing, whereas clinical trails with embryonic stem cells have not yet started.

It is expected to take several years before embryonic stem cells will be entering large-scale clinical trials, since there are a number of hurdles needed to be overcome before embryonic stem cells are ready for clinical trials. Firstly, culture conditions enabling embryonic stem cells to be cultured in the absence of serum or other animal-derived factors, need to be established. This is due to the risk of transmitting disease-causing agents from animals to hu- 
mans. Secondly, only differentiated cells should be transplanted. Undifferentiated embryonic stem cells carry a risk of developing into teratomas when transplanted into immunocompromised patients. Thirdly, mechanisms enabling the transplanted cells to be eliminated in vivo are likely to be a prerequisite for treating serious, but non-life threatening, diseases. If something should go wrong with the transplanted cells, it will be of key importance to have mechanisms enabling neutralization of the transplanted cells. Fourthly, extensive animal experimentation is required in advance of clinical trials on humans. Animal trials are of importance to evaluate toxic side effects and preferably also clinical effect of the treatment. Animal studies on human embryonic stem cells (or derived cells thereof) can, however, be of limited value due to the potential immunological elimination of human cells in the animal and lack of physiological responses due to species differences. Finally, the transplanted cells must be accepted by the recipient's immune system to avoid being rejected. With regard to stem cells this challenge can be overcome by a variety of means. Among the options used today are i) using the patient's own stem cells, ii) cells from a matched donor, and iii) generating large banks of stem cells. Furthermore, stem cells suitable for transplantation can potentially in the future be obtained by iv) parthenogenesis $(6), v)$ generation of pluripotent stem cells by somatic nuclear transfer (therapeutic cloning) (7), or vi) by genetic engineering to generate universal stem cell lines.

Murine embryonic stem cells, which have been studied for several years, have demonstrated an ability to differentiate into a number of cell types. Human embryonic stem cells have also demonstrated their potential to differentiate into a variety of cell types $(12,28)$, whereas only a limited amount of data is available on their potential to differentiate into cells of a par- ticular lineage. It has, however, been demonstrated that even human embryonic stem cells can differentiate with some degree of specificity into endothelial (19), nerve $(3,25,33)$, cardiomyocytes (17), insulin-producing (1) and hematopoietic cells (15), thereby supporting their proposed extensive clinical usefulness.

\section{Conclusion}

Whilst the ethical and political debates about whether or not to allow the use of totipotent cells in research have been fierce, the medical breakthroughs have been rather limited. Four years after the initial publication, we are still far away from initiating clinical trials, and research on embryonic stem cells remains a field in its early days of basic research. The reason for lack of progress can in part be explained by lack of funding (24), limited availability of embryonic stem cells lines (11), and national legislation prohibiting research with human embryos (31). Furthermore, patenting issues and secrecy may have hampered the progress even further.

It is difficult to predict the future usefulness of embryonic stem cells for treating currently incurable human diseases on the basis of their value as a tool in basic research. As mentioned above, there are a number of challenges that need to be solved before large-scale clinical trials with embryonic stem cells can be started. These challenges, and probably others not yet known, must be solved before initiation of large-scale clinical trials. Thus, embryonic stem cells are not likely to be a part of routine clinical practice in the foreseeable future. Their immediate usefulness is therefore likely to be limited to basic research and in various in vitrosystems for several years. In contrast, stem cells from adults are demonstrating potentials not previously anticipated and are increasingly being tested in early-stage clinical trials. It remains, however, to demonstrate if stem cells, regardless of source, at all will be the method of 
choice in the future treatment of any human disease.

A theoretical alternative to developing cells suitable for transplantation from human stem cells is to isolate transplantable cells directly from animals (xenotransplantation). It can be envisaged that xenotransplantation has a similar potential as human stem cells to treat a number of currently incurable diseases. Xenotransplantation is, as human stem cells, however at an early stage of basic research and several key questions needs to be answered before largescale clinical trials can be initiated. Thus, to make strong statements about the future clinical usefulness of either human stem cells or xenotransplantation is currently premature, and as both strategies are still promising, they should actively be investigated further.

\section{References}

1. Assady S, Maor G, Amit M, Itskovitz-Eldor J, Skorecki KL, Tzukerman M: Insulin production by human embryonic stem cells. Diabetes 2001, 50, 1691-1697.

2. Bjornson CR, Rietze RL, Reynolds BA, Magli $M C$, Vescovi $A L$ : Turning brain into blood: a hematopoietic fate adopted by adult neural stem cells in vivo. Science 1999, 283, 534-537.

3. Carpenter MK, Inokuma MS, Denham J, Mujtaba T, Chiu CP, Rao MS: Enrichment of neurons and neural precursors from human embryonic stem cells. Exp Neurol 2001, 172, 383-397.

4. Castro RF, Jackson KA, Goodell MA, Robertson $C S$, Liu H, Shine HD: Failure of bone marrow cells to transdifferentiate into neural cells in vivo. Science 2002, 297, 1299.

5. Chan AW, Dominko T, Luetjens CM, Neuber E, Martinovich C, Hewitson L, Simerly CR, Schatten GP: Clonal propagation of primate offspring by embryo splitting. Science $2000,287,317-$ 319.

6. Cibelli JB, Grant KA, Chapman KB, Cunniff K, Worst T, Green HL, Walker SJ, Gutin PH, Vilner L, Tabar V, Dominko T, Kane J, Wettstein PJ, Lanza RP, Studer L, Vrana KE, West MD: Parthenogenetic stem cells in nonhuman primates. Science 2002, 295, 819.

7. Cibelli JB, Kiessling AA, Cunniff K, Richards $C$,
Lanza RP, West MD: Somatic cell nuclear transfer in humans: pronuclear and early embryonic development. J. regen. Med. 2001, 2, 25.

8. Clarke DL, Johansson CB, Wilbertz J, Veress B, Nilsson E, Karlstrom H, Lendahl U, Frisen J: Generalized potential of adult neural stem cells. Science 2000, 288, 1660-1663.

9. Evans MJ, Kaufman MH: Establishment in culture of pluripotential cells from mouse embryos. Nature (Lond.) 1981, 292, 154-156.

10. Ford CE, Hamerton JH, Barnes WH, Loutit JF: Cytological identification of radiation chimeras. Nature (Lond.) 1956, 177, 452-454.

11. Holden $C$, Vogel $G$ : Stem cell lines. 'Show us the cells,' U.S. researchers say. Science 2002, 297, 923-925.

12. Itskovitz-Eldor J, Schuldiner $M$, Karsenti D, Eden A, Yanuka O, Amit M, Soreq H, Benvenisty $N$ : Differentiation of human embryonic stem cells into embryoid bodies compromising the three embryonic germ layers. Mol. Med. 2000, 6, 88-95.

13. Jackson KA, Mi T, Goodell MA: Hematopoietic potential of stem cells isolated from murine skeletal muscle. Proc. nat Acad. Sci. U.S.A. 1999, 96, 14482-14486.

14. Jiang Y, Jahagirdar BN, Reinhardt RL, Schwartz $R E$, Keene CD, Ortiz Gonzalez XR, Reyes $M$, Lenvik T, Lund T, Blackstad M, Du J, Aldrich S, Lisberg A, Low WC, Largaespada DA, Verfaillie $C M$ : Pluripotency of mesenchymal stem cells derived from adult marrow. Nature (Lond.) 2002, 418, 41-49.

15. Kaufman DS, Hanson ET, Lewis RL, Auerbach R, Thomson JA: Hematopoietic colony-forming cells derived from human embryonic stem cells. Proc. nat. Acad. Sci. U.S.A. 2001, 98, 1071610721.

16. Kawada H, Ogawa M: Bone marrow origin of hematopoietic progenitors and stem cells in murine muscle. Blood 2001, 98, 2008-2013.

17. Kehat I, Kenyagin-Karsenti D, Snir M, Segev H, Amit M, Gepstein A, Livne E, Binah O, ItskovitzEldor J, Gepstein L: Human embryonic stem cells can differentiate into myocytes with structural and functional properties of cardiomyocytes. J. clin. Invest. 2001, 108, 407-414.

18. Labarge MA, Blau HM: Biological progression from adult bone marrow to mononucleate muscle stem cell to multinucleate muscle in fiber response to injury. Cell 2002, 111, 589-601.

19. Levenberg S, Golub JS, Amit M, Itskovitz-Eldor 
$J$, Langer R: Endothelial cells derived from human embryonic stem cells. Proc. nat. Acad. Sci. U.S.A. 2002, 99, 4391-4396.

20. Martin GR: Isolation of a pluripotent cell line from early mouse embryos cultured in medium conditioned by teratocarcinoma stem cells. Proc. nat. Acad. Sci. U.S.A. 1981, 78, 7634-7638.

21. McKinney-Freeman SL, Jackson KA, Camargo FD, Ferrari G, Mavilio F, Goodell MA: Musclederived hematopoietic stem cells are hematopoietic in origin. Proc. nat. Acad. Sci. U.S.A. 2002, 99, 1341-1346.

22. Mezey E, Chandross KJ, Harta G, Maki RA, McKercher SR: Turning blood into brain: cells bearing neuronal antigens generated in vivo from bone marrow. Science 2002, 290, 1779-1782.

23. National Institutes of Health. Stem cells: A Primer. http://www.nih.gov/news/stemcell/ primer.htm 2000.

24. Rowley JD, Blackburn E, Gazzaniga MS, Foster $D W$ : Harmful moratorium on stem cell research. Science 2002, 297, 1957.

25. Schuldiner $M$, Eiges $R$, Eden A, Yanuka O, Itskovitz-Eldor J, Goldstein RS, Benvenisty N: Induced neuronal differentiation of human embryonic stem cells. Brain Res. 2002, 913, 201-205.

26. Shamblott MJ, Axelman J, Wang S, Bugg EM, Littlefield JW, Donovan PJ, Blumenthal PD, Huggins GR, Gearhart JD: Derivation of pluripotent stem cells from cultured human primordial germ cells [published erratum appears in Proc Natl Acad Sci U S A 1999 Feb 2, 96(3), 1162]. Proc. nat. Acad. Sci. U.S.A. 1998, 95, 13726-13731.
27. Terada N, Hamazaki T, Oka M, Hoki M, Mastalerz DM, Nakano Y, Meyer EM, Morel L, Petersen BE, Scott EW: Bone marrow cells adopt the phenotype of other cells by spontaneous cell fusion. Nature (Lond.) 2002, 416, 542-545.

28. Thomson JA, Itskovitz-Eldor J, Shapiro SS, Waknitz MA, Swiergiel JJ, Marshall VS, Jones $J M$ : Embryonic stem cell lines derived from human blastocysts [published erratum appears in Science 1998, 282, 1827]. Science 1998, 282, 1145-1147.

29. Thomson JA, Kalishman J, Golos TG, Durning $M$, Harris $C P$, Becker RA, Hearn JP: Isolation of a primate embryonic stem cell line. Proc. nat. Acad. Sci. U.S.A. 1995, 92, 7844-7848.

30. Till JE, McCulloch EA: A direct measurment of the radiation sensitivity of normal mouse bone marrow cell. Radiat. Res. 1961, 14, 213.

31. Vogel G: Stem cell lines. Regulations constrain stem cell research across the globe. Science 2002, 297, 924.

32. Ying $Q L$, Nichols J, Evans EP, Smith AG: Changing potency by spontaneous fusion. Nature 2002, 416, 545-548.

33. Zhang SC, Wernig M, Duncan ID, Brustle O, Thomson JA: In vitro differentiation of transplantable neural precursors from human embryonic stem cells. Nature Biotechnol. 2002, 19, 1129. 